Article

\title{
Long-Term Green Manure Rotations Improve Soil Biochemical Properties, Yield Sustainability and Nutrient Balances in Acidic Paddy Soil under a Rice-Based Cropping System
}

\author{
Muhammad Qaswar 1,+, Jing Huang 1,2, ${ }^{+}$, Waqas Ahmed ${ }^{1}$, Dongchu Li 1,2, Shujun Liu 1,2, \\ Sehrish Ali ${ }^{1}$, Kailou Liu ${ }^{1,3}$, Yongmei Xu ${ }^{4}$, Lu Zhang ${ }^{1,2}$, Lisheng Liu ${ }^{1,2}$, Jusheng Gao ${ }^{1,2, *}$ and \\ Huimin Zhang 1,2,5,*(D) \\ 1 National Engineering Laboratory for Improving Quality of Arable Land, Institute of Agricultural Resources \\ and Regional Planning, Chinese Academy of Agricultural Sciences, Beijing 100081, China; \\ mqaswar2@gmail.com (M.Q.); huangjing@caas.cn (J.H.); waqasmalik184@hotmail.com (W.A.); \\ lidongchu@caas.cn (D.L.); liushujun@caas.cn (S.L.); Sehrishbakhsh788@outlook.com (S.A.); \\ liukailou@126.com (K.L.); zhanglu01@caas.cn (L.Z.); liulisheng@caas.cn (L.L.) \\ 2 National Observation Station of Qiyang Agri-Ecology System, Institute of Agricultural Resources and \\ Regional Planning, Chinese Academy of Agricultural Sciences, Qiyang 426182, China \\ 3 Jiangxi Institute of Red Soil, National Engineering and Technology Research Center for Red Soil \\ Improvement, Nanchang 330046, China \\ 4 Institute of Soil, Fertilizer and Agricultural Water Conservation, Xinjiang Academy of Agricultural Sciences, \\ Urumqi 830091, China; xym1973@163.com \\ 5 College of Agriculture, Henan University of Science and Technology, Luoyang 471000, China \\ * Correspondence: gaojusheng@caas.cn (J.G.); zhanghuimin@caas.cn (H.Z.) \\ + The authors equally contributed to this work.
}

Received: 4 November 2019; Accepted: 18 November 2019; Published: 20 November 2019

check for updates Abstract: Cultivation of green manure (GM) crops in intensive cropping systems is important for
enhancing crop productivity through soil quality improvement. We investigated yield sustainability,
nutrient stocks, nutrient balances and enzyme activities affected by different long-term (1982-2016)
green manure rotations in acidic paddy soil in a double-rice cropping system. We selected four
treatments from a long-term experiment, including (1) rice-rice-winter fallow as a control treatment
(R-R-F), (2) rice-rice-milkvetch (R-R-M), (3) rice-rice-rapeseed (R-R-R), and (4) rice-rice-ryegrass
(R-R-G). The results showed that different GM rotations increased grain yield and the sustainable
yield index compared with those of the R-R-F treatment. Compared with those of R-R-F, the average
grain yield of early rice in R-R-M, R-R-R, and R-R-G increased by $45 \%, 29 \%$, and $27 \%$, respectively and
that of late rice increased by $46 \%, 28 \%$, and $26 \%$, respectively. Over the years, grain yield increased
in all treatments except R-R-F. Green manure also improved the soil chemical properties (SOM and
total and available $\mathrm{N}$ and P), except soil pH, compared to those of the control treatment. During the
1983-1990 cultivation period, the soil pH of the R-R-M treatment was lower than that of the R-R-F
treatment. The addition of green manure did not mitigate the soil acidification caused by the use of
inorganic fertilizers. The soil organic matter (SOM), total nitrogen (TN) and total phosphorus (TP)
contents and stocks of C, N and P increased over the years. Furthermore, GM significantly increased
phosphatase and urease activities and decreased the apparent $\mathrm{N}$ and P balances compared with those
in the winter fallow treatment. Variance partitioning analysis revealed that soil properties, cropping
systems, and climatic factors significantly influenced annual grain yield. Aggregated boosted tree
(ABT) analysis quantified the relative influences of the different soil properties on annual grain yield
and showed that the relative influences of TN content, SOM, pH, and TP content on annual crop
yield were $27.8 \%, 25.7 \%, 22.9 \%$, and $20.7 \%$, respectively. In conclusion, GM rotation is beneficial for 
sustaining high crop yields by improving soil biochemical properties and reducing $\mathrm{N}$ and $\mathrm{P}$ balances in acidic soil under double- rice cropping systems.

Keywords: Acidic soil; crop rotation; enzyme activities; green manure; sustainable yield index; nutrient balance

\section{Introduction}

Long-term fertility experiments have been important resources for exploring nutrient cycling and performing overall assessments of soil fertility [1]. Long-term experiments provide a platform for investigating crop yield trends, productivity, soil quality, and other factors that contribute to agricultural sustainability [2]. Worldwide, irrigation and fertilization are the two most important factors for obtaining higher agricultural productivity and sustainability [3]. However, other factors, such as climate, pests, cultivars, soil types, and fertilization patterns, also contribute to changing yield trends and sustainability in long-term cropping systems [4].

During the past decades, due to the continuous and unwise use of fertilizers, rice (Oryza sativa) yield has increased significantly, but nutrient use efficiencies have decreased. This over fertilization has not only resulted in economic losses to farmers due to the misuse of expensive fertilizers but has also led to degradation of the soil and affected air, and water quality $[5,6]$. The negative effects of degraded soil quality, such as acidification and poor soil structure, on rice yield have been found in many studies $[7,8]$. Crop rotation with legumes such as green manure (GM) not only improves the soil quality and soil water content by increasing soil organic matter but also increases nutrient availability through atmospheric N fixation with rhizobia [9]. Studies have found that GM decreased the population, species, and density of unwanted weeds in rice fields [10]. Similarly, GM not only improves the soil biological (microbial activities) and physical properties [11,12] but also increases the carbon (C) and $\mathrm{N}$ cycling [13-15]. Furthermore, GM increases the quantity of water-stable macroaggregates in the topsoil and increases the capacity of microbes to mineralize organic $\mathrm{N}$; consequently, it can enhance the $\mathrm{N}$ supply capacity and crop productivity [16,17]. Cultivation of GMs such as Chinese milkvetch (Astragalus sinicus L.) in paddy soils can exploit their natural qualities and improve rice productivity with minimal economic and environmental losses $[18,19]$.

Previous studies of different long-term experiments at different locations have indicated decreasing yield trends after a few years of continuous cropping under rice-wheat (Triticum aestivum) rotations [20]. The cultivation of input-responsive high-yielding cultivars has been increased, compelling farmers to apply high doses of chemical fertilizers. Excessive use of inorganic fertilizers is a common practice to meet the nutrient need of high-yield varieties. Different long-term experiments have indicated that long-term continuous and excessive chemical fertilization degraded the soil quality and increased acidification, which resulted in poor crop sustainability [21,22].

The sustainable yield index (SYI) represents the actual yields over a long period. A higher sustainable yield index indicates that an area will produce an acceptable yield over the years through better cultivation practices [20-22]. SYI is a quantitative measure with which to assess the sustainability of an agricultural practice [23]. Long-term experiments provide one of the means of measuring the sustainability of an agricultural system [2]. Data records from long-term experiments can be used as early warning systems for the future [24]. In China, many long-term fertility experiments have indicated wide variability in crop yields that has been attributed to the continued reduction of soil fertility $[6,25]$. To monitor the long-term fertility and yield response of crops to fertilization, the first step in analyzing long-term experiments is to identify the sustainability of crop productivity. Previous studies have mainly focused on the effects of GM on rice production in short- term experiments or in a single cropping system [26,27]. However, little is known about the benefits of different GM rotations for sustainable rice productivity and nutrient balance, especially in paddy soils under long-term 
rice-based cropping systems [28-30]. The aims of this study were to investigate the effect of different green manure rotations on SYI, crop yield, apparent nutrient balance, and enzyme activities in an acidic paddy soil.

\section{Materials and Methods}

\subsection{Site Description}

A long-term (1982-2016) field experiment was conducted at the red soil experiment station of the Chinese Academy of Agricultural Sciences in Qiyang County $\left(26^{\circ} 45^{\prime} 42^{\prime \prime} \mathrm{N}, 111^{\circ} 52^{\prime} 32^{\prime \prime}\right.$ E), Hunan Province, China. The climate in this region is a humid subtropical monsoon with a mean annual rainfall of $1290 \mathrm{~mm}$. The main rainfall period is from April to the end of June, during the period of early-season rice cultivation. The drought period is from August to October during the late-season rice cultivation period, and the mean annual temperature is $17.8^{\circ} \mathrm{C}$. The mean annual temperature (MAT) and mean annual precipitation (MAP) for the experimental period are shown in Figure S1. The paddy soil of this region is categorized as a Ferralic Cambisol [31], which was made by Quaternary red clay. The initial soil properties were $\mathrm{pH}$ 6.1, soil organic matter (SOM) $20.4 \mathrm{~g} \mathrm{~kg}^{-1}$, total N $0.94 \mathrm{~g} \mathrm{~kg}^{-1}$, total P $0.65 \mathrm{~g} \mathrm{~kg}^{-1}$, total $\mathrm{K} 10.6 \mathrm{~g} \mathrm{~kg}^{-1}$, alkali-hydrolyzed $\mathrm{N} 148 \mathrm{mg} \mathrm{kg}^{-1}$, Olsen-P $17.6 \mathrm{mg} \mathrm{kg}^{-1}$ and

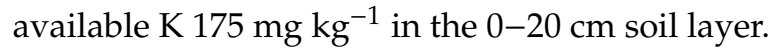

\subsection{Experimental Design}

The four cropping treatments were rice-rice-winter fallow (R-R-F), rice-rice-milkvetch (Astragalus sinicus L.) (R-R-M), rice-rice-rapeseed (Brassica napus L.) (R-R-R) and rice-rice-ryegrass (Lolium multiflorum) (R-R-G). All treatments had three replicates arranged in a randomized complete block design. The area of each replicate was $37.5 \mathrm{~m}^{2}(2.5 \mathrm{~m} \times 15.0 \mathrm{~m})$. Each replicate plot was separated from the adjacent replicates by a $60-\mathrm{cm}$ cement barrier to prevent water and nutrient contamination from the nearby plot. The total fertilizer application rates for each rice growing season were $153 \mathrm{~kg} \mathrm{ha}^{-1} \mathrm{~N}$, $84 \mathrm{~kg} \mathrm{ha}^{-1} \mathrm{P}_{2} \mathrm{O}_{5}$, and $129 \mathrm{~kg} \mathrm{ha}^{-1} \mathrm{~K}_{2} \mathrm{O}$. The compound fertilizer $\left(600 \mathrm{~kg} \mathrm{ha}^{-1}\right)$ containing $14 \%$ each of $\mathrm{N}, \mathrm{P}_{2} \mathrm{O}_{5}$, and $\mathrm{K}_{2} \mathrm{O}$ was applied as basal application 1 day before rice transplantation, while urea and potassium chloride for $\mathrm{N}\left(69 \mathrm{~kg} \mathrm{ha}^{-1}\right)$ and $\mathrm{K}_{2} \mathrm{O}\left(45 \mathrm{~kg} \mathrm{ha}^{-1}\right)$, respectively, were topdressed 6 to 10 days after rice transplantation. Green manure crops were sown in the middle of October after the late rice was harvested and were plowed into the soil as a whole crop before the early rice transplantation (in the first week of April) every year. The seeding rates of milkvetch, rapeseed, and ryegrass were 37.5, 7.5 , and $15.0 \mathrm{~kg} \mathrm{ha}^{-1}$, respectively. Early and late rice seedlings were transplanted with spacing of 20 $\mathrm{cm} \times 20 \mathrm{~cm}$ and $20 \mathrm{~cm} \times 25 \mathrm{~cm}$, respectively, and each hill contained three seedlings. All rice straw (except the rice stubble) was removed from the plots after each seasonal rice harvest. No fertilizer was applied to the green manure crop in winter. The fresh biomass of the incorporated ryegrass, milkvetch, and rapeseed was $5700 \mathrm{~kg} \mathrm{ha}^{-1}, 6000 \mathrm{~kg} \mathrm{ha}^{-1}$, and $6200 \mathrm{~kg} \mathrm{ha}^{-1}$, while the dry matter was $1126 \mathrm{~kg} \mathrm{ha}^{-1}, 1276 \mathrm{~kg} \mathrm{ha}^{-1}$, and $1249 \mathrm{~kg} \mathrm{ha}^{-1}$, respectively. Milkvetch contained $43.7 \% \mathrm{C}$ and $3.9 \% \mathrm{~N}$ contents, ryegrass contained $41.5 \% \mathrm{C}$ and $1.8 \% \mathrm{~N}$ contents, rapeseed contained $42.3 \% \mathrm{C}$ and $1.76 \% \mathrm{~N}$ contents in samples collected in 2017. Conventional routine management practices were used for pest management and irrigation. The rice varieties used locally were selected and were replaced every $3-5$ years (Table S1). Flooding was maintained throughout the early rice season, and the field was drained at the late rice ripening stage $[32,33]$.

\subsection{Sampling and Analysis}

Early and late rice grain and straw samples were manually harvested at six randomly selected points from each plot and weighed. Grain and straw samples were oven-dried at $105^{\circ} \mathrm{C}$ for $30 \mathrm{~min}$ and then heated at $70{ }^{\circ} \mathrm{C}$ to a constant weight for dry matter and total $\mathrm{N}$ and $\mathrm{P}$ determination. Dried grain and straw samples were ground and digested with $\mathrm{H}_{2} \mathrm{SO}_{4}-\mathrm{H}_{2} \mathrm{O}_{2}$ at $260-270{ }^{\circ} \mathrm{C}$. The total plant $\mathrm{N}$ and $\mathrm{P}$ were determined using the semimicro Kjeldahl digestion method and the vanadomolybdate yellow 
method, respectively (Jackson 1969; Nelson and Sommers 1980). The soil samples were collected every year from the starting date of the experiment (1983) to 2016. Soil samples were collected at a depth of 0-20 cm from five randomly selected points in each plot after late rice harvest, and plant materials and stones were removed from the soil. Soil samples were then mixed, air-dried, and sieved $(0.2 \mathrm{~mm})$ for the determination of soil chemical properties. Soil organic carbon (SOC) was determined with the potassium dichromate oxidation method [34], and total N (TN) was determined with the Kjeldahl method [35]. Soil total P (TP) was determined according to Murphy and Riley [36]. Alkali-hydrolyzable mineral N (AN) was determined according to $\mathrm{Lu}$ [37]. Available P (AP) was extracted using $0.5 \mathrm{~mol}$ $\mathrm{L}^{-1} \mathrm{NaHCO}_{3}$, and the measurement of AP was performed by the Olsen method [38].

For enzyme activity determination, soil samples were collected in 2017 after the late rice harvest. Enzyme activities were determined in field-moist soil samples. A portion of the subsamples was used to determine the soil moisture content before the analysis of enzyme activities by oven drying at 105 ${ }^{\circ} \mathrm{C}$ for $24 \mathrm{~h}$. Acid phosphomonoesterase (AcP) and phosphodiesterase (DP) activities were determined following Tabatabai [39]. Briefly, $1 \mathrm{~g}$ of soil was incubated at $37^{\circ} \mathrm{C}$ for $1 \mathrm{~h}$ after adding $p$ - nitrophenyl phosphate as a substrate solution with a buffer solution of $\mathrm{pH} 6.5$ for AcP. DP was assayed using a substrate solution of bis-p-nitrophenyl phosphate with a buffer solution of $\mathrm{pH}$ 8. Urease activity was determined following the colorimetric method [40]. Briefly, $5 \mathrm{~g}$ of moist soil was incubated at $37^{\circ} \mathrm{C}$ for $2 \mathrm{~h}$ after adding urea solution as the substrate. A modified Berthelot reaction was followed to extract the released ammonium by potassium chloride solution. The activities of Acp and DP were expressed as $\mu \mathrm{g} \mathrm{NP} \mathrm{g}{ }^{-1}$ soil $\mathrm{h}^{-1}$, and urease activity was expressed as $\mu \mathrm{g} \mathrm{N} \mathrm{g}^{-1}$ soil $2 \mathrm{~h}^{-1}$.

Stocks (S) of SOC, total $\mathrm{N}$ and total $\mathrm{P}$ were estimated as follows:

$$
S=S O C \times B D \times H \times 10^{-1}
$$

where, $\mathrm{S}$ is the stock (ton ha ${ }^{-1}$ ) of soil organic carbon (SOC), total $\mathrm{N}$ or total $\mathrm{P}$. The concentration of soil organic carbon $\left(\mathrm{g} \mathrm{kg}^{-1}\right)$, total $\mathrm{N}\left(\mathrm{g} \mathrm{kg}^{-1}\right)$ or total $\mathrm{P}\left(\mathrm{g} \mathrm{kg}^{-1}\right)$ is used in the equation. BD is the soil bulk density $\left(\mathrm{g} \mathrm{cm}^{-3}\right)$, and $\mathrm{H}$ is the depth of soil sampling $(\mathrm{cm})$. BD is the soil bulk density $\left(\mathrm{g} \mathrm{cm}^{-3}\right)$, and $\mathrm{H}$ is the depth of soil sampling $(\mathrm{cm})$. In the present study, the soil bulk density was not measured directly from the field and was calculated using the following equation in ref. [41].

$$
B D=-0.0048 \times S O C+1.377
$$

The apparent nutrient balance $(\mathrm{AB})\left(\mathrm{kg} \mathrm{ha}^{-1} \mathrm{year}^{-1}\right)$ is the difference in nutrient inputs to the field through fertilization and nutrient outputs from the field in harvested biomass [42]. The apparent nutrient balance is based on the soil surface (lower plow) balance but does not incorporate the potential losses incurred from runoff or soil erosion. A positive value of the apparent nutrient balance indicates a nutrient surplus, and a negative value of the apparent nutrient balance (nutrient deficit) indicates declining soil fertility [42]. The environmental risk threshold values are $45 \mathrm{~kg} \mathrm{ha}^{-1}$ year ${ }^{-1}$ for the $\mathrm{P}$ balance and $180 \mathrm{~kg} \mathrm{ha}^{-1}$ year ${ }^{-1}$ for the $\mathrm{N}$ balance $[43,44]$. The apparent nutrient balance was estimated using the following equation [44]:

$$
\text { Apparent nutrient balance }=F_{\text {input }}-N_{\text {output }}
$$

where $\mathrm{Fi}_{\text {nput }}$ is the nutrient input from fertilizers and $\mathrm{N}_{\text {output }}$ is nutrient offtake by the crop in the harvested biomass (nutrients assimilated into straw and grains of rice).

\subsection{Sustainable Yield Index (SYI)}

SYI is a quantitative measure with which to assess the sustainability of an agricultural practice [23]. The sustainable yield index (SYI) was estimated using the following equation [45]:

$$
\text { Sustainable Yield Index }(S Y I)=\frac{Y \operatorname{mean}-\sigma}{Y \max }
$$


where $Y_{\text {mean }}$ is the mean yield of a treatment, $\sigma$ is the treatment standard deviation, and $Y_{\text {max }}$ is the maximum yield in the experiment over the years for each treatment.

\subsection{Statistical Analysis}

We evaluated the significant differences among treatments by one-way ANOVA, and interactive effects of treatments and cultivation years were evaluated by two-way ANOVA followed by least significant difference (LSD) test at the $p=0.05$ level significance [46] using SPSS 16.0 software (SPSS, Chicago, IL, USA). Variance partitioning analysis (VPA) was performed to evaluate the contributions of soil factors (soil pH, SOM, total N, and total P), cropping systems, climatic factors (MAT and MAP), and their interactions in changing the annual rice yield over the cropping period (1984-2016) using CANOCO for Windows (version 5.0). Aggregated boosted tree (ABT) analysis was performed to investigate the relative influence of the important soil factors on annual crop yield using the 'gbmplus' package in R software (version 3.3.3) [47].

\section{Results}

\subsection{Crop Yield and Sustainability Index}

The results showed that long-term rotations of different green manure (GM) types in the doublerice cropping system significantly $(p \leq 0.05)$ increased grain yield and sustainable yield index (SYI) compared to those in the winter fallow system (Table 1 and Figure 1). The highest increase in the average grain yield and SYI over the period of early and late season cropping was under the milkvetch rotation (R-R-M). Compared to R-R-F, the average increases in grain yield in R-R-M, R-R-R, and R-R-G were $45 \%, 29 \%$, and $27 \%$, respectively, in early rice and $46 \%, 28 \%$, and $26 \%$, respectively, in late rice. Compared to those in the winter fallow system, crop yields of both early and late rice were increased over the year, but the highest increase was under the R-R-M treatment (Figure 1). The increases in SYI in R-R-M, R-R-R. and R-R-G compared to R-R-F were $36 \%, 21 \%$. and $23 \%$, respectively, in early rice, $24 \%, 20.3 \%$. and $10 \%$, respectively, in late rice and $19 \%, 16 \%$. and $9.5 \%$, respectively, in double-rice cropping systems overall.

Table 1. Effect of long-term green manure rotations on the sustainability yield index (SYI) of double-rice cropping systems in acidic paddy soil.

\begin{tabular}{cccccc}
\hline Treatments & \multicolumn{2}{c}{ Average Grain Yield (kg ha $\left.{ }^{-1}\right)$} & \multicolumn{2}{c}{ Yield Sustainability Index } \\
\hline & $\begin{array}{c}\text { Early Rice } \\
\text { Yield }\end{array}$ & Late Rice Yield & Early Rice & Late Rice & $\begin{array}{c}\text { Double Rice } \\
\text { Cropping }\end{array}$ \\
\hline R-R-F & $4532 \pm 812 \mathrm{c}$ & $4022 \pm 780 \mathrm{c}$ & $0.53 \mathrm{c}$ & $0.59 \mathrm{c}$ & $0.63 \mathrm{c}$ \\
$\mathrm{R}-\mathrm{R}-\mathrm{M}$ & $6559 \pm 819 \mathrm{a}$ & $5859 \pm 741 \mathrm{a}$ & $0.72 \mathrm{a}$ & $0.73 \mathrm{a}$ & $0.75 \mathrm{a}$ \\
$\mathrm{R}-\mathrm{R}-\mathrm{R}$ & $5853 \pm 917 \mathrm{~b}$ & $5135 \pm 623 \mathrm{~b}$ & $0.64 \mathrm{~b}$ & $0.71 \mathrm{a}$ & $0.73 \mathrm{ab}$ \\
R-R-G & $5769 \pm 930 \mathrm{~b}$ & $5076 \pm 728 \mathrm{~b}$ & $0.65 \mathrm{~b}$ & $0.65 \mathrm{~b}$ & $0.69 \mathrm{~b}$ \\
\hline
\end{tabular}

Average grain yield is based on mean of grain yield of all cultivation years (1982-2016). Means followed by different letters are significantly $(p \leq 0.05)$ different from each other according to Tukey's LSD test. 


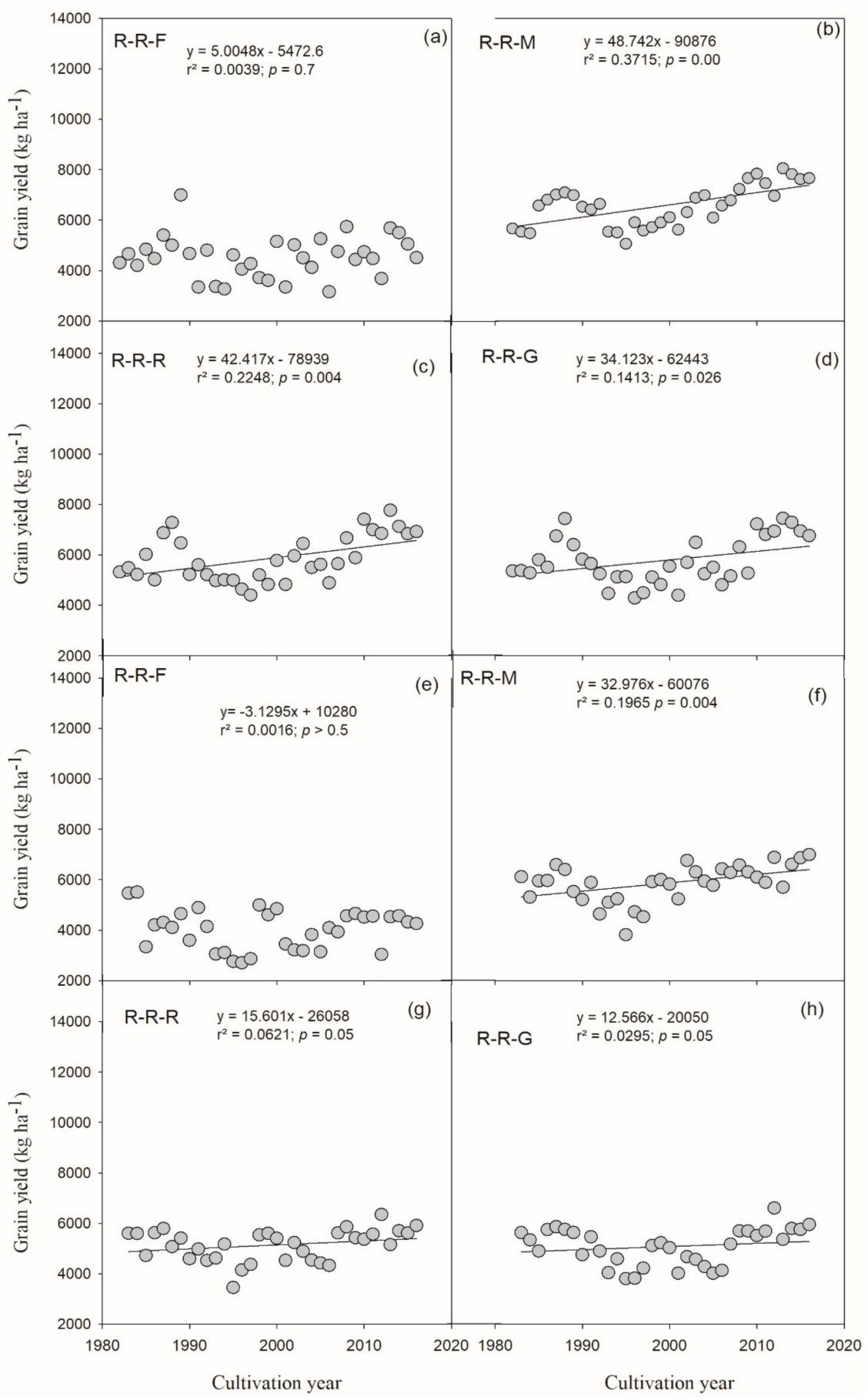

Figure 1. Linear regression showing trends of rice grain yields over the years (1982-2016) under green manure rotations in the rice-based cropping system.

\subsection{Soil Nutrient Content, Nutrient Stocks, and Apparent Nutrient Balance}

The treatment $\times$ year interaction significantly affected soil properties (Table 2). During the fertilization period of 1983-1990, soil pH was not significantly different between the R-R-G and R-R-R treatments. Among all treatments, during 1983-1990, the soil pH was lowest under the R-R-M treatment. The soil $\mathrm{pH}$ under the R-R-F and R-R-M treatments during 1983-1990 was decreased by $0.98 \%$ and $2 \%$ compared to the initial soil $\mathrm{pH}$. During the period of 1991-2000, the soil $\mathrm{pH}$ among all treatments was decreased compared to the soil pH during 1983-1990, and it was highest under the R-R-R treatment. In all treatments, over the years, the SOM content was higher than the initial SOM 
content. Compared to the initial SOM content, the increases in SOM content under the R-R-F, R-R-M, R-R-G, and R-R-R treatments were 7.3\%, 23\%, 12.2\%, and 12.7\%, respectively, during 1983-1990 and $11.3 \%, 20 \%, 15.6 \%$, and $16.6 \%$, respectively, during 1991-2000. The respective increases in SOM content during 2001-2016 under the R-R-F, R-R-M, R-R-G, and R-R-R treatments were 33.8\%, 40.6\%, 36.7\%, and $41.2 \%$, respectively, compared to the initial SOM content. The soil TN content in all treatments was higher in all fertilization periods compared to the initial soil TN content. Compared to that in the R-R-F treatment, the increase in the soil TN content under the R-R-M, R-R-G, and R-R-R treatments was $15.9 \%, 14 \%$, and $7.5 \%$, respectively, during the period $1983-1990$, by $23 \%, 7.0 \%$, and $16 \%$, respectively, during 1991-2000, and by $9.8 \%, 4.6 \%$, and 3.9\%, respectively, during 2001-2016. Over the years, the soil TP content increased in all treatments compared with the initial soil TP content. The soil TP content in the R-R-F, R-R-M, R-R-G, and R-R-R treatments increased by $6 \%, 7.7 \%, 12 \%$, and $7.7 \%$, respectively, during 1983-1990. During 1991-2000, the TP content was highest under the R-R-R treatment and did not show a significant difference among the R-R-F, R-R-M, and R-R-G treatments. During 2001-2016, the soil TP content also did not show a significant difference between the R-R-F and R-R-M treatments or between the R-R-G and R- R-R treatments. After 34 years of cropping, the increases in AN under R-R-M, R-R-R and R-R-G compared to R-R-F were $22 \%, 6.4 \%$, and $16.5 \%$, respectively, in early rice and $11 \%, 6 \%$, and $5.6 \%$, respectively, in late rice (Figure 2). Similarly, compared to R-R-F, the increases in Olsen-P under R-R-M, R-R-R, and R-R-G were $10.5 \%, 25.7 \%$, and $22 \%$, respectively, in early rice and $11.7 \%, 19.3 \%$, and $25.5 \%$, respectively, in late rice. Green manure increased stocks of $C, N$, and $P$ compared to those in the winter fallow treatment (Figure 3). On average, across the years, the soil $C$ and $\mathrm{N}$ stocks were not different between the R-R-R and R-R-G treatments. Over the years, soil C, N, and $\mathrm{P}$ stocks increased in all treatments, and the lowest increase was under the R-R-F treatment.

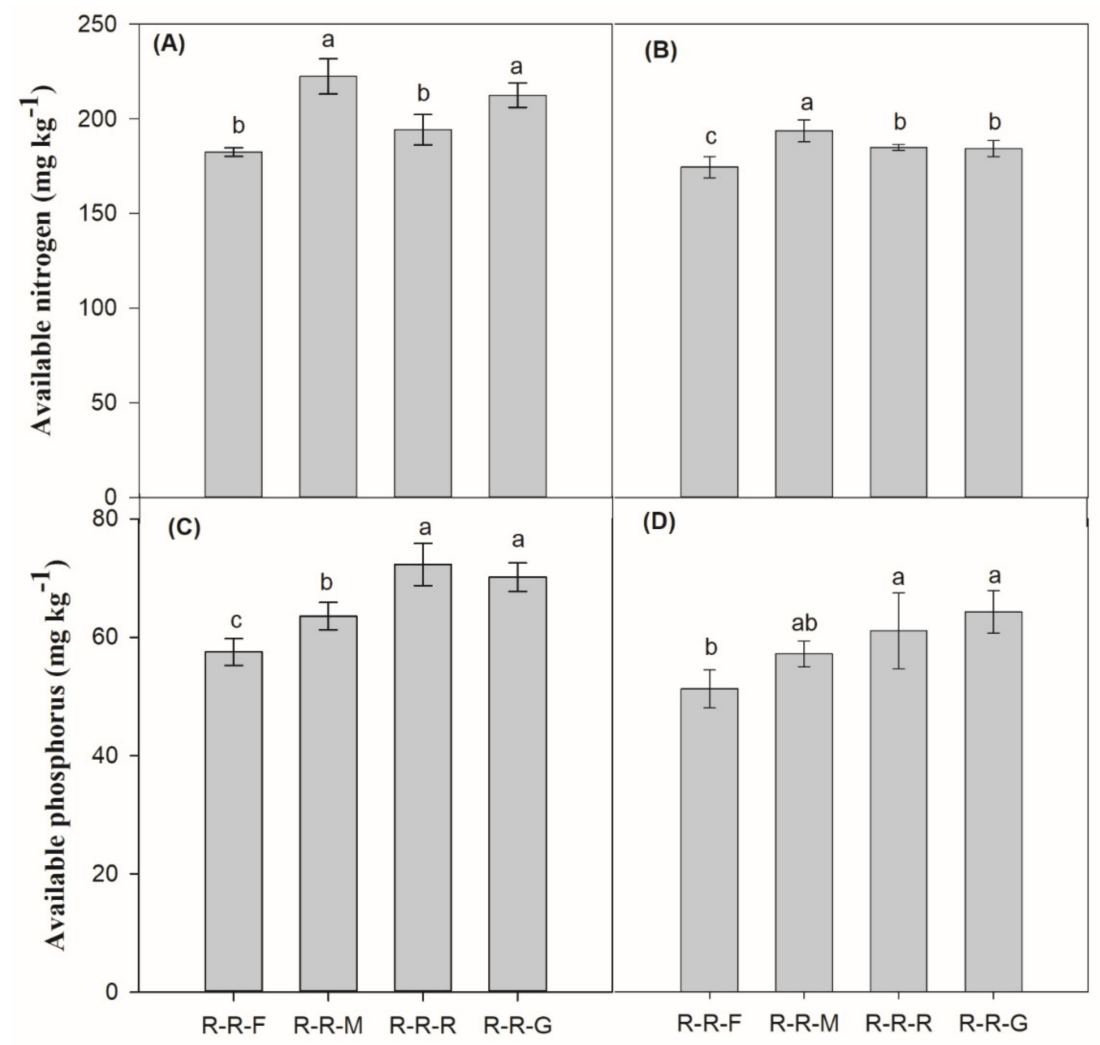

Figure 2. Effect of different long-term green manure rotations on soil available $\mathrm{N}$ after early rice harvest (A) and after late rice harvest (B), and available P after early rice harvest (C) and after late rice harvest (D). Error bars represent \pm standard deviations; different letters over the bars indicate significant $(p \leq$ 0.05) differences according to Tukey's LSD test. 
Table 2. Effect of long-term green manure rotations on soil $\mathrm{pH}$, soil organic matter (SOM), total nitrogen, and total phosphorus content in acidic paddy soil.

\begin{tabular}{|c|c|c|c|c|c|}
\hline Year & Treatment & $\mathrm{pH}$ & SOM ( $\left.\mathrm{g} \mathrm{kg}^{-1}\right)$ & $\mathrm{TN}\left(\mathrm{g} \mathrm{kg}^{-1}\right)$ & $\mathrm{TP}\left(\mathrm{g} \mathrm{kg}^{-1}\right)$ \\
\hline Initial values & & 6.1 & 20.4 & 0.94 & 0.65 \\
\hline \multirow[t]{4}{*}{ 1983-1990 } & R-R-F & $6.04 \pm 0.06 b c$ & $21.9 \pm 0.34 c$ & $1.07 \pm 0.03 c$ & $0.69 \pm 0.01 b$ \\
\hline & R-R-M & $5.98 \pm 0.07 c$ & $25.1 \pm 0.29 \mathrm{a}$ & $1.24 \pm 0.03 \mathrm{a}$ & $0.70 \pm 0.02 b$ \\
\hline & R-R-G & $6.07 \pm 0.07 \mathrm{ab}$ & $22.9 \pm 0.84 b$ & $1.22 \pm 0.02 \mathrm{a}$ & $0.74 \pm 0.02 \mathrm{a}$ \\
\hline & R-R-R & $6.13 \pm 0.01 \mathrm{a}$ & $23.0 \pm 0.57 \mathrm{~b}$ & $1.15 \pm 0.01 b$ & $0.70 \pm 0.02 b$ \\
\hline \multirow[t]{4}{*}{ 1991-2000 } & R-R-F & $5.45 \pm 0.03 c$ & $22.7 \pm 0.45 c$ & $1.13 \pm 1.01 \mathrm{~d}$ & $0.90 \pm 0.02 b$ \\
\hline & R-R-M & $5.70 \pm 0.13 \mathrm{a}$ & $24.5 \pm 0.44 \mathrm{a}$ & $1.39 \pm 0.02 \mathrm{a}$ & $0.91 \pm 0.02 b$ \\
\hline & R-R-G & $5.57 \pm 0.04 b$ & $23.6 \pm 0.51 b$ & $1.21 \pm 0.02 c$ & $0.89 \pm 0.04 b$ \\
\hline & R-R-R & $5.80 \pm 0.04 \mathrm{a}$ & $23.8 \pm 0.35 b$ & $1.31 \pm 0.02 b$ & $0.96 \pm 0.04 \mathrm{a}$ \\
\hline \multirow[t]{4}{*}{ 2001-2016 } & R-R-F & $5.78 \pm 0.05 \mathrm{~ns}$ & $27.3 \pm 0.52 c$ & $1.67 \pm 0.03 c$ & $1.11 \pm 0.03 b$ \\
\hline & R-R-M & $5.83 \pm 0.08$ & $28.7 \pm 0.34 \mathrm{a}$ & $1.84 \pm 0.09 \mathrm{a}$ & $1.13 \pm 0.08 b$ \\
\hline & R-R-G & $5.77 \pm 0.04$ & $27.9 \pm 0.50 \mathrm{a}$ & $1.75 \pm 0.03 b$ & $1.26 \pm 0.08 \mathrm{a}$ \\
\hline & R-R-R & $5.87 \pm 0.08$ & $28.8 \pm 0.43 b$ & $1.74 \pm 0.04 b$ & $1.22 \pm 0.07 \mathrm{a}$ \\
\hline \multirow{3}{*}{ Two-way ANOVA } & Treatment $(\mathrm{T})$ & $* * *$ & $* * *$ & $* * *$ & $* * *$ \\
\hline & Year $(Y)$ & $* * *$ & $* * *$ & $* * *$ & $* * *$ \\
\hline & $\mathrm{T} \times \mathrm{Y}$ & $* * *$ & $* * *$ & $* * *$ & $*$ \\
\hline
\end{tabular}

Values are means \pm standard deviations. Means followed by different letters are significantly $(p \leq 0.05)$ different from each other according to Tukey's LSD test. * Significant $(p \leq 0.05) . * * *$ Very highly significant $(p \leq 0.001)$. ns: nonsignificant $(p>0.05)$. Note: We divided the long-term (1983-2016) data into three groups by taking the average of years $1983-1990,1991-2000$, and 2001-2016 to better describe the long-term changes in the results. 

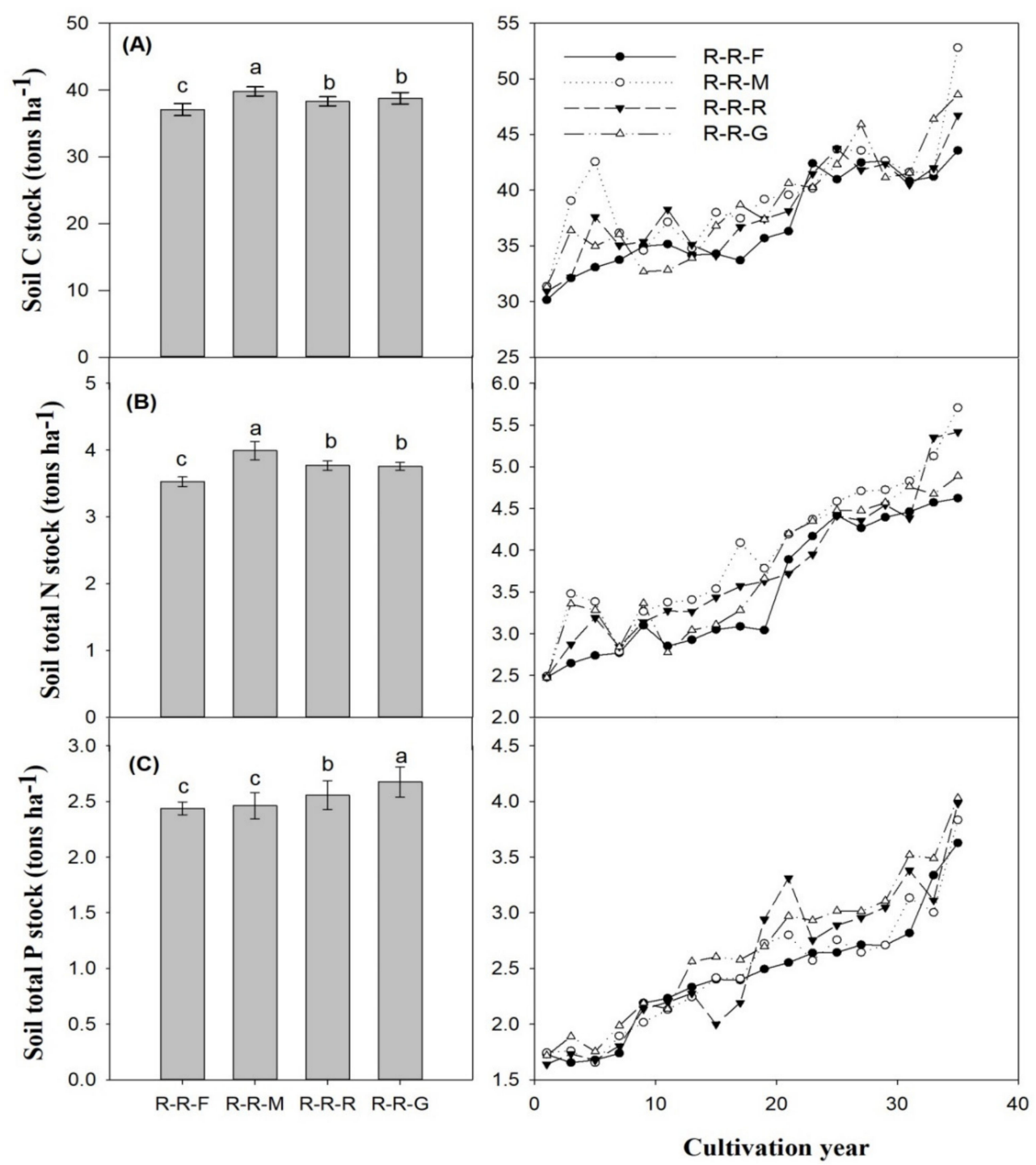

Figure 3. Effect of different long-term green manure rotations on stocks of soil organic carbon (A), total $\mathrm{N}(\mathrm{B})$ and total $\mathrm{P}(\mathrm{C})$ in acidic paddy soil. Error bars represent \pm standard deviations; different letters over the bars indicate significant $(p \leq 0.05)$ differences according to Tukey's LSD test.

GM rotations significantly $(p \leq 0.05)$ influenced the annual apparent $\mathrm{N}$ and $\mathrm{P}$ balance in the longterm experiment on the double-rice cropping system (Figure 4). In the control treatment (R- R- F), the apparent $\mathrm{N}$ and $\mathrm{P}$ balances were highest compared with those in all other $\mathrm{GM}$ treatments. The annual N balance in the R-R-M, R-R-R and R-R-R treatments was decreased by $38 \%, 21 \%$, and $24 \%$, respectively, and the annual $P$ balance was decreased by $36 \%, 27 \%$, and $34 \%$, respectively, compared with those of R-R-F in the double-rice cropping system. 


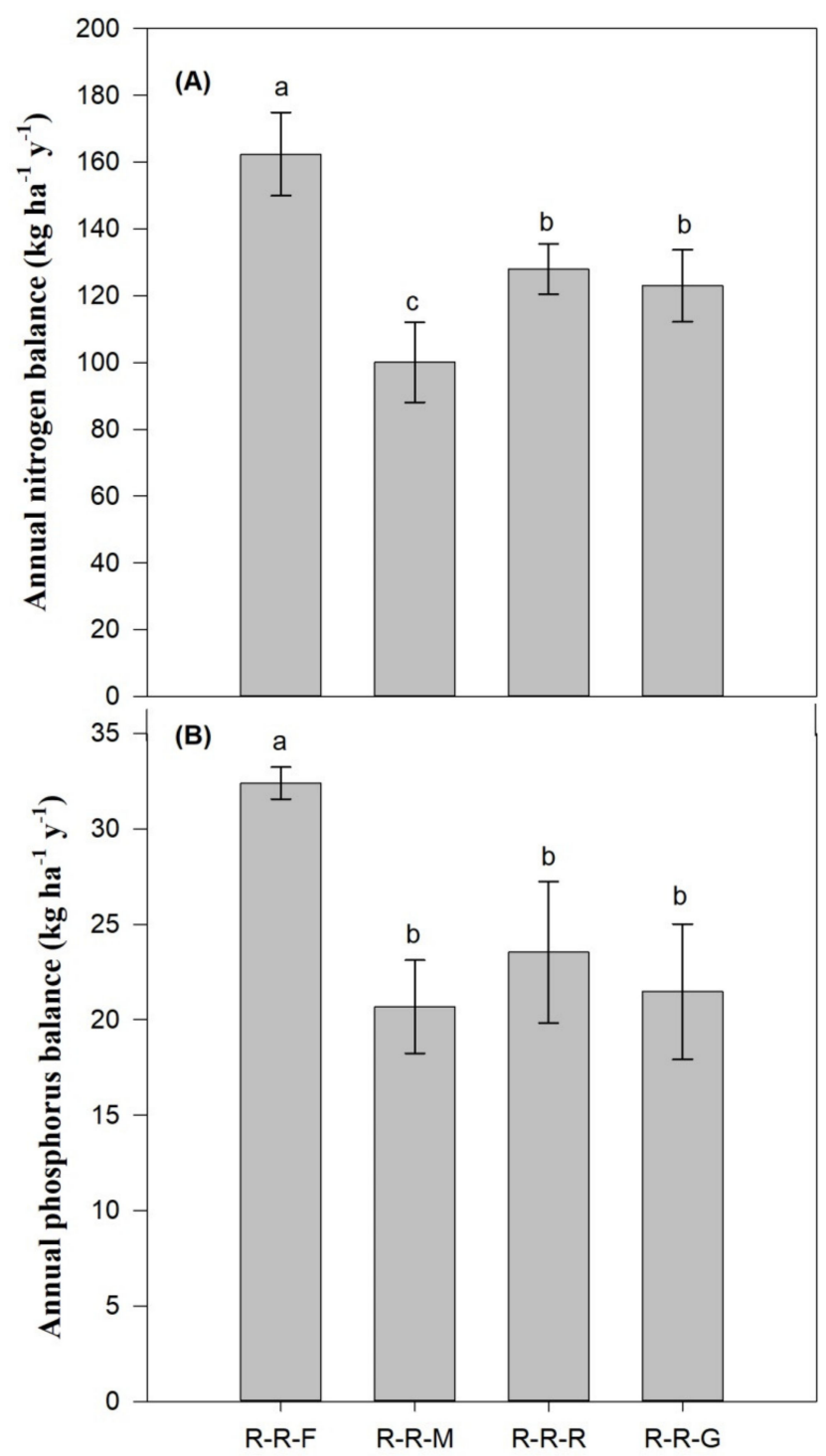

Figure 4. Effect of different long-term green manure rotations on annual apparent (A) N and (B) P balances in acidic paddy soil. Error bars represent \pm standard deviations; different letters over the bars indicate significant $(p \leq 0.05)$ differences according to Tukey's LSD test.

\subsection{Enzyme Activities}

Different long-term GM rotations significantly influenced phosphatase and urease activities (Figure 5). Acid phosphomonoesterase (AcP), phosphodiesterase (DP), and urease activities were highest in the R-R-M treatment and lowest in the R-R-F treatment. Compared with those in the control, the R-R-M, R-R-R, and R-R-G treatments increased AcP activity by $68 \%, 52 \%$, and $50 \%$, DP activity by $83 \%, 70 \%$, and $65 \%$ and urease activity by $72 \%, 20 \%$, and $25 \%$, respectively. Available $\mathrm{N}$ and $\mathrm{P}$ significantly positively affected AcP and DP activities (Figure S2). Available N also showed significant positive linear relationship with urease activities. 


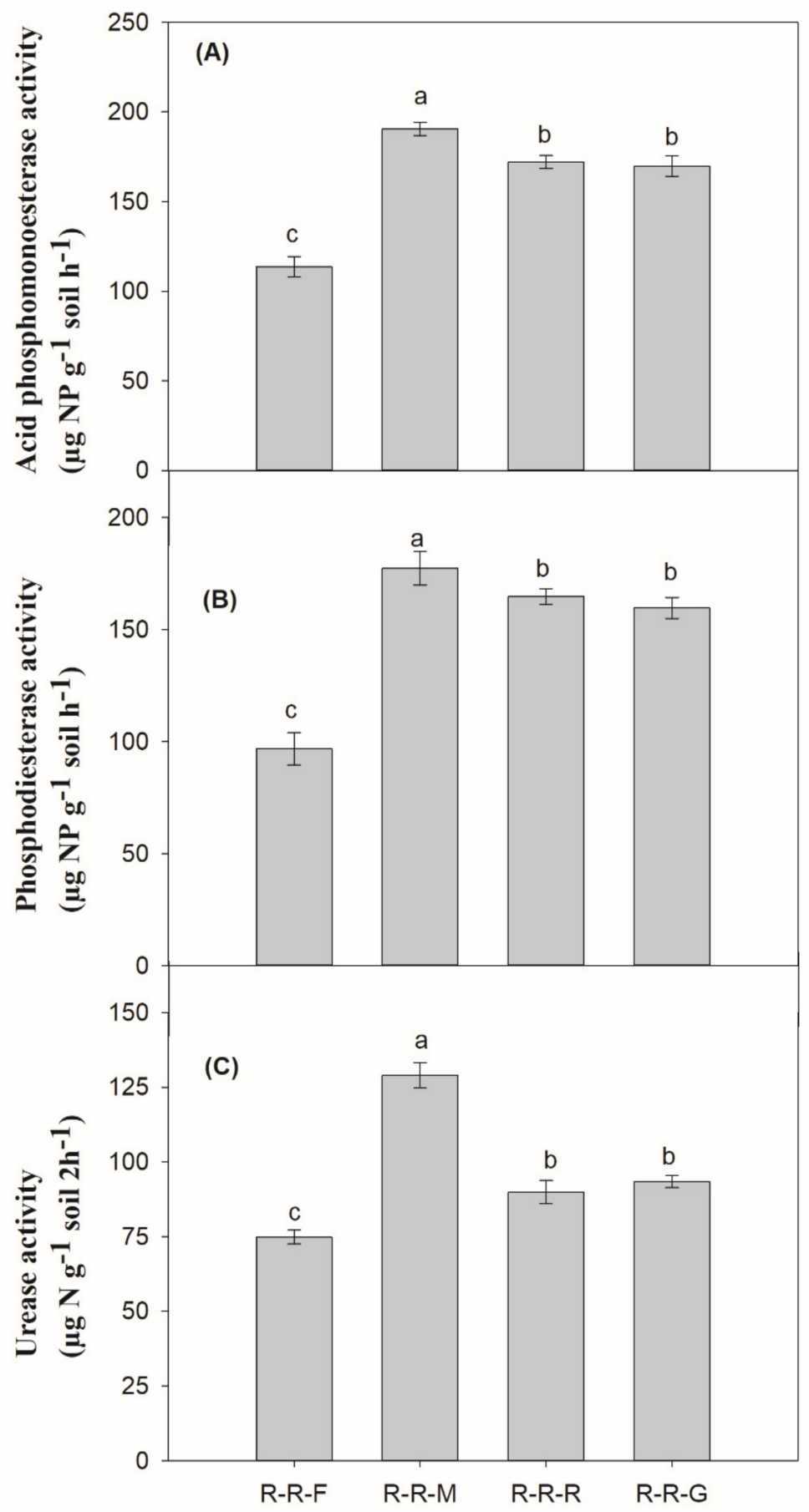

Figure 5. Effect of different long-term green manure rotations on enzyme activities in acidic paddy soil. Error bars represent \pm standard deviations; different letters over the bars indicate significant $(p \leq 0.05)$ differences according to Tukey's LSD test.

\subsection{Factors Influencing Crop Yield}

We investigated the contributions of different factors influencing crop yield by variance partitioning analysis and aggregated boosted tree (ABT) analysis. The changes in early and late rice yield over the long period of cropping were due to variations in different soil and climatic factors in the long-term double-cropping system. Variance partitioning analysis showed that soil properties $(\mathrm{pH}, \mathrm{SOM}$, total N, and total $\mathrm{P}$ ) accounted for $11.3 \%$ of the variation, the cropping system accounted for $8.8 \%$, and climatic factors (MAT and MAP) accounted for $4.6 \%$ of the variation in annual grain yield. The total variance 
explained by VPA was $36 \%$, and the unexplained proportion was $64 \%$ for annual grain yield (Figure 6 ). Aggregated boosted tree (ABT) analysis indicated that soil TN, SOM, soil $\mathrm{pH}$, and soil TP contents were the most influential factors on crop yield (Figure 7).

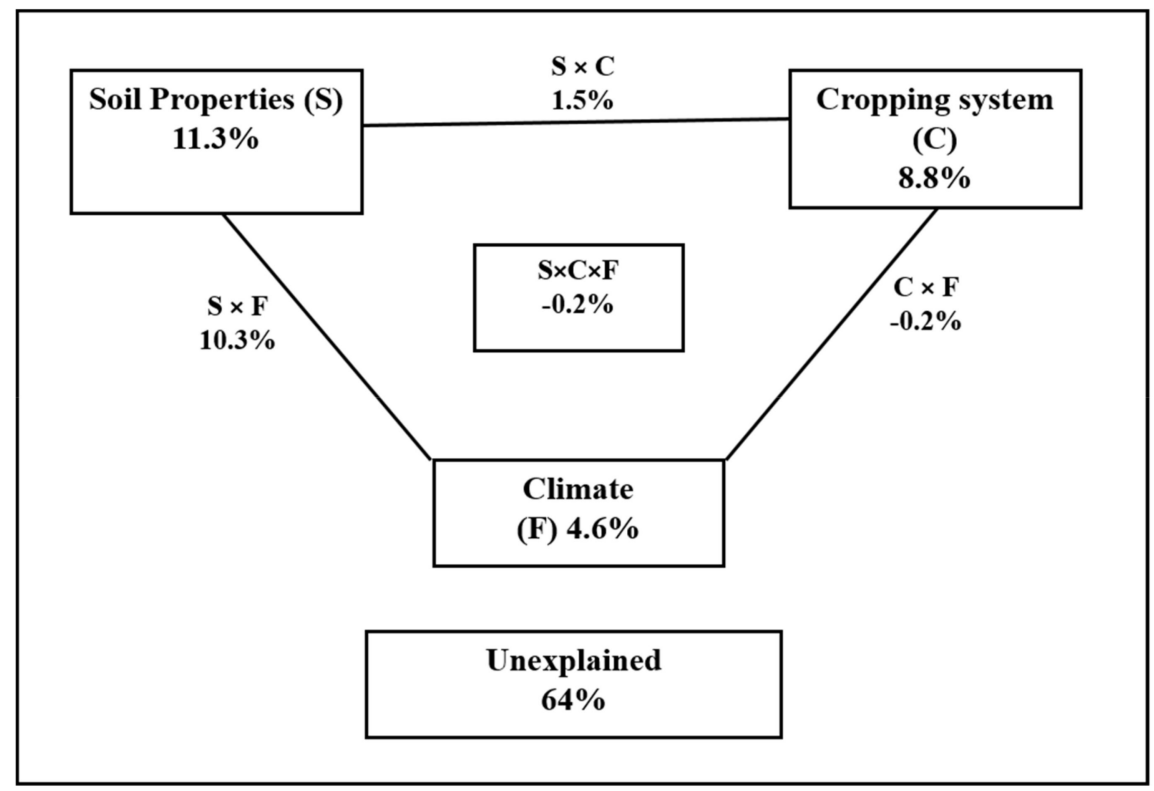

Figure 6. Variance partitioning analysis (VPA) indicating the effects of soil properties, cropping systems, and climatic factors on annual crop yield under long-term green manure rotations in rice-based cropping systems.

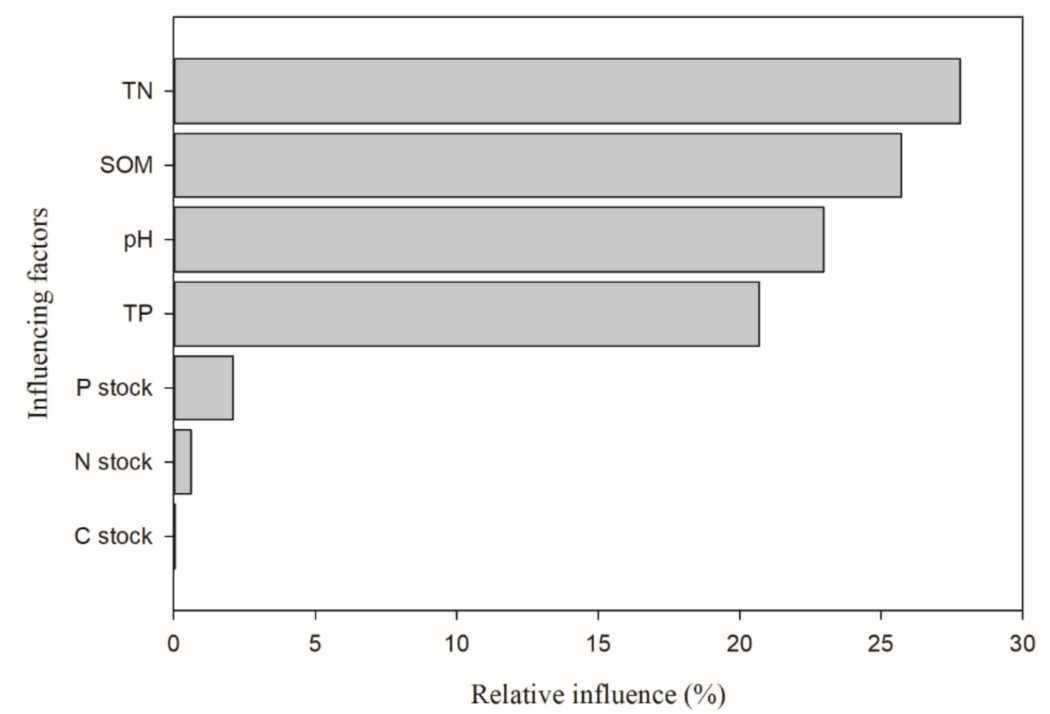

Figure 7. Relative influence (\%) of different predictors on annual crop yield by aggregated boosted tree (ABT) analysis. Long-term data (1983-2016) were used for ABT analysis.

\section{Discussion}

The sustainability yield index (SYI) is considered a major indicator of agricultural sustainability for crop production and soil fertility management $[48,49]$. A high SYI indicates a more sustainable cropping system [29]. In this study, different long-term (34-year) GM rotations significantly $(p \leq 0.05)$ increased grain yield and sustainability yield index (SYI) values compared to those of a winter fallow system in acidic soil under a double-rice cropping system (Table 1 and Figure 1). The highest increases in grain yield and SYI for both early and late rice were under the milkvetch rotation because milkvetch 
is a leguminous species that provides a large quantity of biologically fixed $\mathrm{N}$ for better plant growth and production [33]. GM rotation improves the soil properties and nutrient supply capacity [28]. Yang et al. [32] found that GM increased both the quality and quantity of SOM and had a positive impact on soil nutrient availability, which helped to increase the sustainability of rice yield. However, in previous studies, long-term experiments showed declining trends in grain yield under rice-rice and rice-wheat cropping systems [20,50]. In our results, the R-R-F treatment decreased the crop yield over the years (Figure 1). It has been shown that in double-cropping systems, long-term inorganic fertilization may decrease the crop yield over the years due to decreasing soil quality, including through increasing soil acidification $[29,51,52]$. In long-term experiments, different factors such as climate and soil properties influence productivity over the long cultivation period. In our study, soil properties, cropping systems, and climate significantly influenced crop yield. These results are consistent with previous studies, indicating the influence of soil properties and climate (mean annual temperature and mean annual precipitation) on rice yield $[53,54]$. However, in our VPA analysis results, the unexplained proportion was $64 \%$, which was higher than the explained proportion. This might be due to the same rates of inorganic fertilization being applied in all cropping treatments because fertilizer is one of the main influencing factors on crop yield in long-term fertility experiments $[55,56]$.

Soil fertility is one of the main indicators for measuring the sustainability of cropping systems [28,57]. Our results showed that GM increased nutrient contents and stocks compared to those under the winter fallow treatment, and the highest increase in available $\mathrm{N}$ content was under the R-R-M treatment (Figure 2). Non-leguminous cover crops decrease nutrient leaching and enhance nutrient availability [58]. Leguminous cover crops enhance $\mathrm{N}$ availability and therefore increase crop yield by improving $\mathrm{N}$ use efficiency [27]. The ability of legumes to fix atmospheric molecular dinitrogen into mineral $\mathrm{N}$ for plant uptake makes legumes the most efficient GM [59]. The decreasing trend in soil $\mathrm{pH}$ could have been due to long-term synthetic fertilization [28]. Lin et al. [51] also observed a declining trend in soil $\mathrm{pH}$ in paddy soil under long-term fertilization. Many studies observed soil acidification caused by long- term inorganic fertilization [51,60]. Moreover, plants release net $\mathrm{H}^{+}$ions; on the other hand, when the uptake of anions exceeds the cation uptake, they release a net excess of $\mathrm{OH}^{-}$or $\mathrm{HCO}_{3}{ }^{-}$[61]. It was also observed in previous studies that $\mathrm{N}$ fertilization shifted the soil to the $\mathrm{Al}^{3+}$ buffering stage. $\mathrm{Al}$ is released in soil solution from the surface of clay minerals during the hydrolysis process of $\mathrm{Al}$ hydroxides at a relatively low soil $\mathrm{pH}$, which may also decrease the amount of base cations and increase the soil acidity [62]. However, the alkaline nature of GM neutralizes the protons in acidic soil and helps to improve soil $\mathrm{pH}$ [63]. GM can also help to improve soil physical and chemical properties by improving soil porosity $[17,64]$ and structure, reducing leaching $[65]$ and increasing water holding capacity $[32,66]$, thereby providing suitable conditions for proper plant growth to sustain long-term crop yield.

Nutrient release in soil from decaying SOM under long-term GM application increases the soil enzyme activities [67]. Leguminous cover crops change the microbial community in rhizosphere soil and increase the enzyme activities [33]. Moreover, available $\mathrm{N}$ and $\mathrm{P}$ showed significant positive relationship with enzyme activities (Figure S2), which indicate that higher enzyme activities enhance the nutrient availability and their uptake by crop, that may reduce the nutrient balance in the present study. The decreases in the annual $\mathrm{N}$ and $\mathrm{P}$ balances were consistent with the results of Balík et al., [68] but different from the results found by Ladha et al., [69] probably because the crop yield in the study by Ladha et al. [69] was not significantly different after GM rotation compared with the yields obtained by chemical fertilization. In this study, the lowest annual $\mathrm{N}$ balance was under the Chinese milkvetch rotation, possibly because the Chinese milkvetch increased crop yield and $\mathrm{N}$ uptake more than the ryegrass and rapeseed rotations $[33,70,71]$. In addition, the magnitude of the annual $\mathrm{P}$ balance reduction was less than that of the annual $\mathrm{N}$ balance (Figure 4). This finding was supported by a previous study conducted in Tianjin [72]. However, the annual P balances among all three GM treatments were not significantly different. The annual $\mathrm{P}$ balance is mainly controlled by soil abiotic 
factors (soil properties and climate) or biological factors (microorganisms) and is less affected by the GM species [73], which was consistent with our findings.

\section{Conclusions}

We have concluded that green manure rotation in a rice-based cropping system significantly increased crop yield sustainability by increasing soil nutrient availability and enzyme activities in acidic paddy soil. The highest increase in crop yield was under the rice-rice-milkvetch rotation system. However, green manure crops did not mitigate soil acidity due to the long-term addition of inorganic fertilizer during the early and late rice seasons. Green manure also decreased the apparent $\mathrm{N}$ and $\mathrm{P}$ balances by increasing the $\mathrm{N}$ and $\mathrm{P}$ uptake compared to those in winter fallow in rice-based cropping systems. The soil properties, cropping system, and climatic conditions significantly contributed to changing the annual crop yield over the experimental period. Among the soil properties, TN, SOM, $\mathrm{pH}$, and TP were the most influential factors on crop yield. Therefore, the cultivation of green manure in rice-based cropping systems could be helpful for enhancing crop yield sustainability but might not be very effective for mitigating soil acidity under long-term inorganic fertilization in acidic paddy soil. Moreover, GM crops could be helpful for minimizing the environmental losses of $\mathrm{N}$ and $\mathrm{P}$ by decreasing the apparent $\mathrm{N}$ and $\mathrm{P}$ balances.

Supplementary Materials: The following are available online at http://www.mdpi.com/2073-4395/9/12/780/s1, Figure S1: Long-term (1983-2016) mean annual temperature and precipitation during the period of experiment of GM rotation in double rice cropping system, Figure S2: Linear regression analysis indicating relationships of enzyme activities with available nitrogen and available Phosphorus under long-term green manure rotation in rice based cropping system, Table S1: The name of cultivars of rice sown in this experiment from 2009 to 2018.

Author Contributions: Conceptualization, M.Q. and J.H.; methodology, D.L.; software, S.L.; validation, S.A. and K.L.; formal analysis, Y.X.; investigation, L.L.; resources, J.G.; data curation, M.Q.; writing-original draft preparation, M.Q.; writing-review and editing, W.A. and L.Z.; visualization, S.L.; supervision, H.Z.; project administration, H.Z.; funding acquisition, H.Z.

Funding: This research was supported by the National Key Research and Development Program of China (2016YFD0300901, 2016YFD0300902 and 2017YFD0800101), the National Natural Science Foundation of China (Nos. 41671301, 41371293 and 41561070), and the Fundamental Research Funds for Central Non-profit Scientific Institution (No.161032019035, No.161032019020).

Acknowledgments: We acknowledge the staff at the Qiyang long-term experiment sites for the technical support in collecting soil samples.

Conflicts of Interest: The authors declare no conflict of interest.

\section{References}

1. Shahid, M.; Shukla, A.K.; Bhattacharyya, P.; Tripathi, R.; Mohanty, S.; Kumar, A.; Lal, B.; Gautam, P.; Raja, R.; Panda, B.B.; et al. Micronutrients (Fe, Mn, $\mathrm{Zn}$ and $\mathrm{Cu}$ ) balance under long-term application of fertilizer and manure in a tropical rice-rice system. J. Soils Sediments 2016, 16, 737-747. [CrossRef]

2. Rasmussen, P.E. Long-term agroecosystem experiments: Assessing agricultural sustainability and global change. Science. 1998, 282, 893-896. [CrossRef] [PubMed]

3. Liang, H.; Hu, K.; Batchelor, W.D.; Qi, Z.; Li, B. An integrated soil-crop system model for water and nitrogen management in North China. Sci. Rep. 2016, 6, 25755. [CrossRef] [PubMed]

4. $\quad$ Singh, R.J.; Ghosh, B.N.; Sharma, N.K.; Patra, S.; Dadhwal, K.S.; Meena, V.S.; Deshwal, J.S.; Mishra, P.K. Effect of seven years of nutrient supplementation through organic and inorganic sources on productivity, soil and water conservation, and soil fertility changes of maize-wheat rotation in north-western Indian Himalayas. Agric. Ecosyst. Environ. 2017, 249, 177-186. [CrossRef]

5. Melero, S.; Porras, J.C.R.; Herencia, J.F.; Madejon, E. Chemical and biochemical properties in a silty loam soil under conventional and organic management. Soil Tillage Res. 2006, 90, 162-170. [CrossRef]

6. Liu, C.-A.; Li, F.-R.; Zhou, L.-M.; Zhang, R.-H.; Yu, J.; Lin, S.-L.; Wang, L.-J.; Siddique, K.H.M.; Li, F.-M. Effect of organic manure and fertilizer on soil water and crop yields in newly-built terraces with loess soils in a semi-arid environment. Agric. Water Manag. 2013, 117, 123-132. [CrossRef] 
7. Guo, J.H.; Liu, X.J.; Zhang, Y.; Shen, J.L.; Han, W.X.; Zhang, W.F.; Christie, P.; Goulding, K.W.T.; Vitousek, P.M.; Zhang, F.S. Significant acidification in major Chinese croplands. Science. 2010, 327, 1008-1010. [CrossRef]

8. Liu, X.; Zhang, Y.; Han, W.; Tang, A.; Shen, J.; Cui, Z.; Vitousek, P.; Erisman, J.W.; Goulding, K.; Christie, P.; et al. Enhanced nitrogen deposition over China. Nature 2013, 494, 459-462. [CrossRef]

9. Nyfeler, D.; Huguenin-Elie, O.; Suter, M.; Frossard, E.; Lüscher, A. Grass-legume mixtures can yield more nitrogen than legume pure stands due to mutual stimulation of nitrogen uptake from symbiotic and non-symbiotic sources. Agric. Ecosyst. Environ. 2011, 140, 155-163. [CrossRef]

10. Norsworthy, J.K.; Brandenberger, L.; Burgos, N.R.; Riley, M. Weed suppression in Vigna unguiculata with a spring-seeded brassicaceae green manure. Crop Prot. 2005, 24, 441-447. [CrossRef]

11. Zhang, Q.-C.; Shamsi, I.H.; Xu, D.-T.; Wang, G.-H.; Lin, X.-Y.; Jilani, G.; Hussain, N.; Chaudhry, A.N. Chemical fertilizer and organic manure inputs in soil exhibit a vice versa pattern of microbial community structure. Appl. Soil Ecol. 2012, 57, 1-8. [CrossRef]

12. Bedini, S.; Avio, L.; Sbrana, C.; Turrini, A.; Migliorini, P.; Vazzana, C.; Giovannetti, M. Mycorrhizal activity and diversity in a long-term organic Mediterranean agroecosystem. Biol. Fertil. Soils 2013, 49, 781-790. [CrossRef]

13. Tejada, M.; Gonzalez, J.L.; García-Martínez, A.M.; Parrado, J. Effects of different green manures on soil biological properties and maize yield. Bioresour. Technol. 2008, 99, 1758-1767. [CrossRef] [PubMed]

14. Piotrowska, A.; Wilczewski, E. Effects of catch crops cultivated for green manure and mineral nitrogen fertilization on soil enzyme activities and chemical properties. Geoderma 2012, 189-190, 72-80. [CrossRef]

15. Bedada, W.; Karltun, E.; Lemenih, M.; Tolera, M. Long-term addition of compost and NP fertilizer increases crop yield and improves soil quality in experiments on smallholder farms. Agric. Ecosyst. Environ. 2014, 195, 193-201. [CrossRef]

16. Liu, Y.-R.; Li, X.; Shen, Q.-R.; Xu, Y.-C. Enzyme activity in water-stable soil aggregates as affected by long-term application of organic manure and chemical fertiliser. Pedosphere 2013, 23, 111-119. [CrossRef]

17. Kumar, S.; Patra, A.K.; Singh, D.; Purakayastha, T.J. Long-term chemical fertilization along with farmyard manure enhances resistance and resilience of soil microbial activity against heat stress. J. Agron. Crop Sci. 2014, 200, 156-162. [CrossRef]

18. Crews, T.; Peoples, M. Legume versus fertilizer sources of nitrogen: Ecological tradeoffs and human needs. Agric. Ecosyst. Environ. 2004, 102, 279-297. [CrossRef]

19. Voisin, A.-S.; Guéguen, J.; Huyghe, C.; Jeuffroy, M.-H.; Magrini, M.-B.; Meynard, J.-M.; Mougel, C.; Pellerin, S.; Pelzer, E. Legumes for feed, food, biomaterials and bioenergy in Europe: A review. Agron. Sustain. Dev. 2014, 34, 361-380. [CrossRef]

20. Ram, S.; Singh, V.; Sirari, P. Effects of 41 years of application of inorganic fertilizers and farm yard manure on crop yields, soil quality, and sustainable yield index under a rice-wheat cropping system on Mollisols of North India. Commun. Soil Sci. Plant Anal. 2016, 47, 179-193. [CrossRef]

21. Choudhary, M.; Panday, S.C.; Meena, V.S.; Singh, S.; Yadav, R.P.; Mahanta, D.; Mondal, T.; Mishra, P.K.; Bisht, J.K.; Pattanayak, A. Long-term effects of organic manure and inorganic fertilization on sustainability and chemical soil quality indicators of soybean-wheat cropping system in the Indian mid-Himalayas. Agric. Ecosyst. Environ. 2018, 257, 38-46. [CrossRef]

22. Das, A.; Sharma, R.P.; Chattopadhyaya, N.; Rakshit, R. Yield trends and nutrient budgeting under a long-term (28 years) nutrient management in rice-wheat cropping system under subtropical climatic condition. Plant Soil Environ. 2014, 60, 351-357. [CrossRef]

23. Wanjari, R.H.; Singh, M.V.; Ghosh, P.K. Sustainable yield index: An approach to evaluate the sustainability of long-term intensive cropping systems in India. J. Sustain. Agric. 2004, 24, 39-56. [CrossRef]

24. Dawe, D.; Dobermann, A.; Moya, P.; Abdulrachman, S.; Singh, B.; Lal, P.; Li, S.Y.; Lin, B.; Panaullah, G.; Sariam, O. How widespread are yield declines in long-term rice experiments in Asia? Field Crop. Res. 2000, 66, 175-193. [CrossRef]

25. Xin, X.; Qin, S.; Zhang, J.; Zhu, A.; Yang, W.; Zhang, X. Yield, phosphorus use efficiency and balance response to substituting long-term chemical fertilizer use with organic manure in a wheat-maize system. F. Crop. Res. 2017, 208, 27-33. [CrossRef]

26. Ashraf, M.; Mahmood, T.; Azam, F.; Qureshi, R.M. Comparative effects of applying leguminous and non-leguminous green manures and inorganic $\mathrm{N}$ on biomass yield and nitrogen uptake in flooded rice (Oryza sativa L.). Biol. Fertil. Soils 2004, 40, 147-152. [CrossRef] 
27. Zhao, X.; Wang, S.; Xing, G. Maintaining rice yield and reducing $N$ pollution by substituting winter legume for wheat in a heavily-fertilized rice-based cropping system of southeast China. Agric. Ecosyst. Environ. 2015, 202, 79-89. [CrossRef]

28. Xie, Z.; Tu, S.; Shah, F.; Xu, C.; Chen, J.; Han, D.; Liu, G.; Li, H.; Muhammad, I.; Cao, W. Substitution of fertilizer-N by green manure improves the sustainability of yield in double-rice cropping system in south China. Field Crop. Res. 2016, 188, 142-149. [CrossRef]

29. Yadav, R.; Dwivedi, B.; Pandey, P. Rice-wheat cropping system: Assessment of sustainability under green manuring and chemical fertilizer inputs. Field Crop. Res. 2000, 65, 15-30. [CrossRef]

30. Hong, X.; Ma, C.; Gao, J.; Su, S.; Li, T.; Luo, Z.; Duan, R.; Wang, Y.; Bai, L.; Zeng, X. Effects of different green manure treatments on soil apparent $\mathrm{N}$ and $\mathrm{P}$ balance under a 34-year double-rice cropping system. J. Soils Sediments 2019, 19, 73-80. [CrossRef]

31. Baxter, S. World Reference Base for Soil Resources; World Soil Resources Report 103; Food and Agriculture Organization of the United Nations: Rome, Italy, 2006; p. 132. ISBN 92-5-10511-4.

32. Yang, Z.; Xu, M.; Zheng, S.; Nie, J.; Gao, J.; Liao, Y.; Xie, J. Effects of long-term winter planted green manure on physical properties of reddish paddy soil under a double-rice cropping system. J. Integr. Agric. 2012, 11, 655-664. [CrossRef]

33. Zhang, X.; Zhang, R.; Gao, J.; Wang, X.; Fan, F.; Ma, X.; Yin, H.; Zhang, C.; Feng, K.; Deng, Y. Thirty-one years of rice-rice-green manure rotations shape the rhizosphere microbial community and enrich beneficial bacteria. Soil Biol. Biochem. 2017, 104, 208-217. [CrossRef]

34. Pages, A.L.; Miller, R.H.; Dennis, R.K. Methods of Soil Analysis. Part 2 Chemical Methods; Soil Science Society of America Inc.: Madison, WI, USA, 1982.

35. Black, C.A. Methods of Soil Analysis Part II. Chemical and Microbiological Properties; American Society of Agriculture: Madison, WI, USA, 1965.

36. Murphy, J.; Riley, J.P. A modified single solution method for the determination of phosphate in natural waters. Anal. Chim. Acta 1964, 27, 31-36. [CrossRef]

37. Lu, R.K. Analytical Methods of Soil Agricultural Chemistry; China Agricultural Science and Technology Press: Beijing, China, 2000.

38. Olsen, S.R. Estimation of Available Phosphorus in Soils by Extraction with Sodium Bicarbonate; US Dept. of Agriculture: Washington, DC, USA, 1954.

39. Tabatabai, M.A. Methods of Soil Analysis. Part 2: Microbiological and Biochemical Properties; Mickelson, S.H.J.M.B., Ed.; Soil Science Society of America: Madison, WI, USA, 1994; pp. 775-833.

40. Kandeler, E.; Gerber, H. Short-term assay of soil urease activity using colorimetric determination of ammonium. Biol. Fertil. Soils 1988, 6, 68-72. [CrossRef]

41. Song, G.; Li, L.; Pan, G.; Zhang, Q. Topsoil organic carbon storage of China and its loss by cultivation. Biogeochemistry 2005, 74, 47-62. [CrossRef]

42. OECD. OECD Compendium of Agri-Environmental Indicators; OECD: Paris, France, 2013; ISBN 9789264181151.

43. Bai, Z.; Li, H.; Yang, X.; Zhou, B.; Shi, X.; Wang, B.; Li, D.; Shen, J.; Chen, Q.; Qin, W.; et al. The critical soil P levels for crop yield, soil fertility and environmental safety in different soil types. Plant Soil 2013, 372, $27-37$. [CrossRef]

44. Ouyang, W.; Li, Z.; Liu, J.; Guo, J.; Fang, F.; Xiao, Y.; Lu, L. Inventory of apparent nitrogen and phosphorus balance and risk of potential pollution in typical sloping cropland of purple soil in China-A case study in the Three Gorges Reservoir region. Ecol. Eng. 2017, 106, 620-628. [CrossRef]

45. Singh, P.R.; Rao, S.K.; Das Bhaskarrao, U.M.; Ready, M.N. Sustainability Index under Different Management: Annual Report; CRIDA: Hydarabad, India, 1990.

46. Steel, R.G.D.; Torrie, J.H.; Dickey, D.A. Principles and Procedures of Statistics: A Biological Approach; McGrawHill Book Compay: New York, NY, USA, 1997.

47. De'Ath, G. Boosted trees for ecological modeling and prediction. Ecology 2007, 88, 243-251. [CrossRef]

48. Manna, M.C.; Swarup, A.; Wanjari, R.H.; Ravankar, H.N.; Mishra, B.; Saha, M.N.; Singh, Y.V.; Sahi, D.K.; Sarap, P.A. Long-term effect of fertilizer and manure application on soil organic carbon storage, soil quality and yield sustainability under sub-humid and semi-arid tropical India. Field Crop. Res. 2005, 93, $264-280$. [CrossRef]

49. Tirol-Padre, A.; Ladha, J.K. Integrating rice and wheat productivity trends using the SAS mixed-procedure and meta-analysis. Field Crop. Res. 2006, 95, 75-88. [CrossRef] 
50. Shahid, M.; Nayak, A.K.; Shukla, A.K.; Tripathi, R.; Kumar, A.; Mohanty, S.; Bhattacharyya, P.; Raja, R.; Panda, B.B. Long-term effects of fertilizer and manure applications on soil quality and yields in a sub-humid tropical rice-rice system. Soil Use Manag. 2013, 29, 322-332. [CrossRef]

51. Lin, H.; Jing, C.M.; Wang, J.H. The influence of long-term fertilization on soil acidification. Adv. Mater. Res. 2014, 955-959, 3552-3555. [CrossRef]

52. Cai, Z.; Wang, B.; Xu, M.; Zhang, H.; He, X.; Zhang, L.; Gao, S. Intensified soil acidification from chemical $\mathrm{N}$ fertilization and prevention by manure in an 18-year field experiment in the red soil of southern China. J. Soils Sediments 2015, 15, 260-270. [CrossRef]

53. Prabnakorn, S.; Maskey, S.; Suryadi, F.X.; Fraiture, C. De Rice yield in response to climate trends and drought index in the Mun River Basin, Thailand. Sci. Total Environ. 2018, 621, 108-119. [CrossRef] [PubMed]

54. Oladele, S.O.; Adeyemo, A.J.; Awodun, M.A. Influence of rice husk biochar and inorganic fertilizer on soil nutrients availability and rain-fed rice yield in two contrasting soils. Geoderma 2019, 336, 1-11. [CrossRef]

55. Gai, X.; Liu, H.; Liu, J.; Zhai, L.; Yang, B.; Wu, S.; Ren, T.; Lei, Q.; Wang, H. Long-term benefits of combining chemical fertilizer and manure applications on crop yields and soil carbon and nitrogen stocks in North China Plain. Agric. Water Manag. 2018, 208, 384-392. [CrossRef]

56. Meena, B.P.; Biswas, A.K.; Singh, M.; Chaudhary, R.S.; Singh, A.B.; Das, H.; Patra, A.K. Long-term sustaining crop productivity and soil health in maize-chickpea system through integrated nutrient management practices in Vertisols of central India. Field Crop. Res. 2019, 232, 62-76. [CrossRef]

57. Tirol-Padre, A.; Ladha, J.K.; Regmi, A.P.; Bhandari, A.L.; Inubushi, K. Organic Amendments Affect Soil Parameters in Two Long-Term Rice-Wheat Experiments. Soil Sci. Soc. Am. J. 2007, 71, 442. [CrossRef]

58. Doltra, J.; Gallejones, P.; Olesen, J.E.; Hansen, S.; Frøseth, R.B.; Krauss, M.; Stalenga, J.; Jończyk, K.; Martínez-Fernández, A.; Pacini, G.C. Simulating soil fertility management effects on crop yield and soil nitrogen dynamics in field trials under organic farming in Europe. Field Crop. Res. 2019, 233, 1-11. [CrossRef]

59. Thorup-Kristensen, K.; Magid, J.; Jensen, L.S. Catch crops and green manures as biological tools in nitrogen management in temperate zones. In Advances in Agronomy; Academic Press: Cambridge, MA, USA, 2003; Volume 79, pp. 227-302. ISBN 0120007975.

60. Zhu, Q.; Liu, X.; Hao, T.; Zeng, M.; Shen, J.; Zhang, F.; Vries, W. De Modeling soil acidi fi cation in typical Chinese cropping systems. Sci. Total Environ. 2018, 613-614, 1339-1348. [CrossRef]

61. Tang, C.; Conyers, M.K.; Nuruzzaman, M.; Poile, G.J.; Liu, D.L. Biological amelioration of subsoil acidity through managing nitrate uptake by wheat crops. Plant Soil 2011, 338, 383-397. [CrossRef]

62. Stevens, C.J.; Dise, N.B.; Gowing, D.J. Regional trends in soil acidification and exchangeable metal concentrations in relation to acid deposition rates. Environ. Pollut. 2009, 157, 313-319. [CrossRef] [PubMed]

63. Rukshana, F.; Butterly, C.R.; Xu, J.-M.; Baldock, J.A.; Tang, C. Organic anion-to-acid ratio influences pH change of soils differing in initial pH. J. Soils Sediments 2013, 14, 407-444. [CrossRef]

64. Srinivasarao, C.; Venkateswarlu, B.; Lal, R.; Singh, A.K.; Kundu, S.; Vittal, K.P.R.; Patel, J.J.; Patel, M.M. Long-term manuring and fertilizer effects on depletion of soil organic carbon stocks under pearl millet-cluster beans-castor rotation in Western India. Land Degrad. Dev. 2014, 25, 173-183. [CrossRef]

65. Thorup-Kristensen, K.; Dresbøll, D.B.; Kristensen, H.L. Crop yield, root growth, and nutrient dynamics in a conventional and three organic cropping systems with different levels of external inputs and $\mathrm{N}$ re-cycling through fertility building crops. Eur. J. Agron. 2012, 37, 66-82. [CrossRef]

66. Fließbach, A.; Oberholzer, H.-R.; Gunst, L.; Mäder, P. Soil organic matter and biological soil quality indicators after 21 years of organic and conventional farming. Agric. Ecosyst. Environ. 2007, 118, 273-284. [CrossRef]

67. Piotrowska-Długosz, A.; Wilczewski, E. Changes in enzyme activities as affected by green-manure catch crops and mineral nitrogen fertilization. Zemdirbyste Agric. 2014, 101, 139-146. [CrossRef]

68. Balík, J.; Černý, J.; Tlustoš, P.; Zitková, M. Nitrogen balance and mineral nitrogen content in the soil in a long experiment with maize under different systems of $N$ fertilization. Plant Soil Environ. 2011, 49, 554-559. [CrossRef]

69. Ladha, J.K.; Dawe, D.; Ventura, T.S.; Singh, U.; Ventura, W.; Watanabe, I. Long-term effects of urea and green manure on rice yields and nitrogen balance. Soil Sci. Soc. Am. J. 2000, 64, 1993. [CrossRef]

70. Zhang, X.-X.; Gao, J.-S.; Cao, Y.-H.; Ma, X.-T.; He, J.-Z. Long-term rice and green manure rotation alters the endophytic bacterial communities of the rice root. Microb. Ecol. 2013, 66, 917-926. [CrossRef] 
71. Gabriel, J.L.; Muñoz-Carpena, R.; Quemada, M. The role of cover crops in irrigated systems: Water balance, nitrate leaching and soil mineral nitrogen accumulation. Agric. Ecosyst. Environ. 2012, 155, 50-61. [CrossRef]

72. Yang, J.; Gao, W.; Ren, S.R. Response of soil phosphorus to P balance under long-term fertilization in fluvo-aquic soil. Sci. Agric. Sin. 2015, 48, 4738-4747.

73. Blake, L.; Mercik, S.; Koerschens, M.; Moskal, S.; Poulton, P.R.; Goulding, K.W.T.; Weigel, A.; Powlson, D.S. Phosphorus content in soil, uptake by plants and balance in three European long-term field experiments. Nutr. Cycl. Agroecosyst. 2000, 56, 263-275. [CrossRef]

(C) 2019 by the authors. Licensee MDPI, Basel, Switzerland. This article is an open access article distributed under the terms and conditions of the Creative Commons Attribution (CC BY) license (http://creativecommons.org/licenses/by/4.0/). 